Island Studies Journal, Vol. 12, No. 1, pp. 151-168

\title{
Tout le monde a sa place? MIRAB, education, and society in Wallis and Futuna
}

\author{
Alice Jacobs \\ Victoria University of Wellington, New Zealand \\ alice.jacobs@vuw.ac.nz
}

and

\author{
John Overton \\ Victoria University of Wellington, New Zealand \\ John.Overton@vuw.ac.nz
}

\begin{abstract}
Wallis and Futuna officially became a 'Sub-National Island Jurisdiction' (known as French Overseas Territory/Collectivity) in 1961 and has since adopted an economic and political structure consistent with the MIgration, Remittances, Aid, and Bureaucracy (MIRAB) model. Although the MIRAB economy has been stable, the rapid increase in migration for higher education of the younger population since the turn of the century raises questions concerning the role of education within this structure. A qualitative study discovered that education should be regarded as a key component in the MIRAB economy of the territory. Firstly, education has provided a new population outlet as young people have chosen opportunities for higher education and training overseas. Secondly, migration for education has revealed social dimensions within the model, as access to education overseas has simultaneously sustained the bureaucratic elite but has also enabled customary classes to negotiate their power and maintain a hold on the process of change. Finally, education has potentially reduced the pressure of remittances, as some qualified graduates are able to return and access high wage employment locally.
\end{abstract}

Keywords: Wallis and Futuna, migration, education, MIRAB, employment

https://doi.org/10.24043/isj.10

(C) 2017 - Institute of Island Studies, University of Prince Edward Island, Canada.

\section{Introduction}

Bertram and Watters (1985) developed a model to explain why very small Pacific Island states and territories often had weak export performance, yet benefitted from a relatively high standard of living. They argued that, unlike less isolated and larger developing countries, small islands were dependent on resources from the metropolitan patron. This dependency prompted a reliance on four main variables: MIgration, Remittances, Aid, and Bureaucracy (MIRAB).

Since their publication, there has been growing interest in the 'propensity for dependency' (McElroy \& Pearce, 2006) for small insular territories and different studies have indicated that, in the majority of cases, Sub-National Island Jurisdictions (SNIJs) do better than independent islands (Baldacchino \& Milne, 2006; Baldacchino, 2006a, 2006b; Bertram 1986, 1993, 2006; Bertram \& Watters, 1985; Ogden, 1989; Poirine, 1993, 1994, 1998; Treadgold, 1999; Watters, 1987). As Baldacchino (2006b, p. 862) argues, non-sovereign small isolated islands have developed "creative solutions" to the challenges they face through utilising resources available to them in the 
'hinterland' (Baldacchino, 2006a). ${ }^{1}$ Although unorthodox to common understandings of economic development, the notion of dependency has been highly present in the literature as a positive form of stability. Bertram (2006) compared this phenomenon to a kaleidoscope to illustrate how these economies operate within an political and social equilibrium subject to unpredictable shifts of external factors. These shifts then create a new 'pattern' or new stability within the islands (Bertram, 2006, p. 12). The notion of relative stability, albeit within the context of periodic externally induced shifts, is important for it builds into a narrative of sustainability, resilience, and well-being (Bertram, 1986; 1993) to counter competing notions of failure, dependence, and fragility that are often associated with small island states (for example Hughes, 2003).

In this research, we question whether education-a critical component in development theory and policy and goal number four in the UN-sponsored Sustainable Development Goals-could be a force affecting the MIRAB model. For small Pacific islands, emigration of skilled people is a critical concern and the question of whether these islands can benefit from education is contextualised within the enduring 'brain drain' and 'brain gain' debate (Beine et al., 2008; Gibson \& McKenzie, 2012). Despite ample research in this field, such concerns regarding potential skill drain have not yet clearly been situated within a MIRAB context. However, it is a topic that ought to be addressed since an increase in education in the hopes of increasing economic autonomy and growth within a society with MIRAB characteristics presents a potential paradox. Education in such a structure may have a role that diverges from traditional understandings of education for sustainable development: does education-and higher education in particular-in the MIRAB context enhance development through higher remittances or return of skilled personnel or does it instead lead to a loss of the young and the brightest and thus a key development resource?

Specifically, in this research, we explore the impact of access to higher education and vocational training on the MIRAB economy of Wallis and Futuna. In the past 20 years, a growing number of young people of Wallis and Futuna have migrated to metropolitan France, New Caledonia, and French Polynesia to pursue higher education (Vakala, 2008; IEOM, 2015; INSEE, 2014). The local authorities and the French State support this migration in the hope, in theory, of increasing human capital in the territory, but many graduates do not return. Migration for education, in combination with labour migration, has contributed to depopulation ${ }^{2}$, particularly amongst the young, and the future impact of this phenomenon is uncertain.

This paper is adapted from a wider research project on the role of higher education in the MIRAB economy of Wallis and Futuna (Jacobs, 2016). The research sought to determine whether migration for higher education was contributing to a "brain drain" or "brain gain" in the MIRAB economy of Wallis and Futuna and to assess how education was affecting the MIRAB structure.

Current research on the MIRAB model in the Pacific has predominantly been informed by quantitative methods and with a focus on the economic sustainability of the model. Here, we took a qualitative social constructivist grounded theory approach to inform the research process in an effort to bring a social/cultural dimension to the model. Through the use of the Pacifika talanoa ${ }^{3}$ interview method (focus groups and individual interviews), we were able to collect interpretations from a total of 60 local and expatriate (metropolitan French) research participants. The participants ranged from young high school students, returnees (graduates and non-graduates), government officials (local politicians and bureaucratic officials), and teachers. The interviews took place in Wallis, Futuna, and New Caledonia.

\footnotetext{
1 'Hinterland' here refers to the (often metropolitan) countries and territories that are linked through close political and constitutional ties and to which island citizens have relatively free access. The hinterland of Wallis and Futuna is thus comprised of New Caledonia and metropolitan France, as well as other territories such as French Polynesia. ${ }^{2}$ Wallis and Futuna experienced a population decline of $2 \%$ per annum between the two most recent censuses (2003 and 2008) (Pacific Community 2016).

${ }^{3}$ The Pacific research method known as talanoa is an open conversation-based interview method (Vaioleti, 2006).
} 


\section{The MIRAB model and its variants}

The acronym MIRAB, coined by Bertram and Watters in 1985, identified that in small Pacific islands (dependent and independent alike) traditional understandings of development based on productive economic growth and economic independence were not viable or representative of the experience of smaller islands (Bertram, 1986, 1993). Instead, links appear to provide stable and higher aid transfers, migration flows, transnational networks, remittances, access to labour markets abroad, and a large bureaucratic presence in the islands (Bertram \& Watters, 1985).

However, this framework could be criticised by development practitioners, government officials, and scholars (Evans, 1999; Poirine, 1998), and may frustrate donors (Watters, 1987, p. 43). Pacific Island scholars, such as Epeli Hau'ofa (1995), also have been sharply critical of such frameworks which seem to emphasise dependency and the primacy of metropolitan structures, rather than the dynamic agency of Pacific Island people who are adept at operating within a wider 'Oceanic' world.

Nevertheless, like Bertram (1986), Poirine (1998) suggests that the MIRAB model potentially provides the best opportunity for small Pacific islands to benefit from international trade and allows Pacific Island people to be freer in their choices of lifestyle (Poirine, 1998, p. 86). In particular, Bertram (2006) and Watters (1987) stated that in a MIRAB economy 'productive' activities to promote development were generally underused or required additional subsidies, whereas the 'unproductive' activities funded by metropolitan centres such as education and health services were more valuable to the communities. Due to this, MIRAB researchers assert that 'dependent development' (Bertram, 1986, p. 809) for small Pacific Islands where there are significant barriers to local development (such as limited export opportunities, limited resources, etc.) is a viable alternative and more sustainable than the promotion of 'self-reliance' (Bertram, 1986, 1993; Bertram \& Watters, 1985; Poirine, 1998).

Although MIRAB literature has been accused of being overly focussed on economic aspects (Poirine, 1994) and lacking social dimensions (Evans, 1999), Watters did address the influence of the MIRAB system on the local social class structure and his findings are of interest to this study. He pointed to a 'new social formation' promoted by the 'economic foundation' of the MIRAB model, particularly causing the expansion of a new powerful 'outward-looking' bureaucratic class (Watters, 1987, p. 35). As a result, he identified that better job security and higher wages in the bureaucracy decreased the appeal of lower-paid cashcropping employment (Watters, 1987, p. 42). Watters also anticipated a crowding out of populations who did not have access to job security in the bureaucratic sector and a possible spread of a 'safety valve' bureaucratic sector based on sinecure employment.

Of particular interest to this study, Poirine $(1994,1996)$ investigated the applicability of MIRAB components to French Overseas Departments and Territories (FODTs) where emigration possibilities are 'unlimited'. Although emigration and remittances are a key component in FODTs, Poirine (1994, p. 2007-8) argued that waged employment (particularly in the high-waged public sector), social benefits (unemployment, allowances, etc.), aid, and other rent activities sometimes offset the need for emigration and act as a substitute for remittances. However, contrary to MIRAB assumptions, Poirine (1994) claimed that a decreased need for migration, populations waiting to access high-waged employment in the public sector (often higher in FODTs than overseas), and limited economic activity (driven out by high wages in the public sector) also forged higher unemployment levels in the islands.

Similarly, in some contexts as in Niue, access to other financial support such as government wages meant remittances were not as important in the foundation of their economy and standards of living (Matheson, 1989 cited in Connell, 2008, p. 1030). Ogden (1994 cited in Connell, 2008, p. 1030) called these economies MIAB economies instead. 
Adding to this alternative understanding of development in the Pacific, Baldacchino and Milne (2006) argue that SNIJs have negotiated metropolitan ties and jurisdictional status to benefit the local interests. Baldacchino (2006a, p. 54) suggested that some small islands have gained control over People, Resources, Overseas management, FInance and Transport - called the PROFIT model. Rather than distinguishing the two models (MIRAB and PROFIT) as separate entities, Baldacchino placed small island economies on a MIRAB-PROFIT spectrum whereby island economies can experience varying degrees of the two extremities (2006a, p. 55).

Around the same time, McElroy (2006) provided another model challenging the MIRAB model called 'Small Island Tourist Economies' (SITES). Extensive research into the SITE model presents tourism as a viable and efficient form of island development (McElroy, 2006; McElroy \& Pearce, 2006; McElroy \& Parry, 2012; McElroy \& Hamma, 2010). In contrast to the MIRAB economies, the PROFIT and SITE economies appear to be more 'demographically mature', often have more dynamic economies and experience an immigration/emigration dynamic (McElroy \& Pearce, 2006; McElroy \& Hamma, 2010; McElroy, 2006; Oberst \& McElroy, 2007; Baldacchino, 2006a; 2006b).

\section{Figure 1: Location of Wallis and Futuna.}

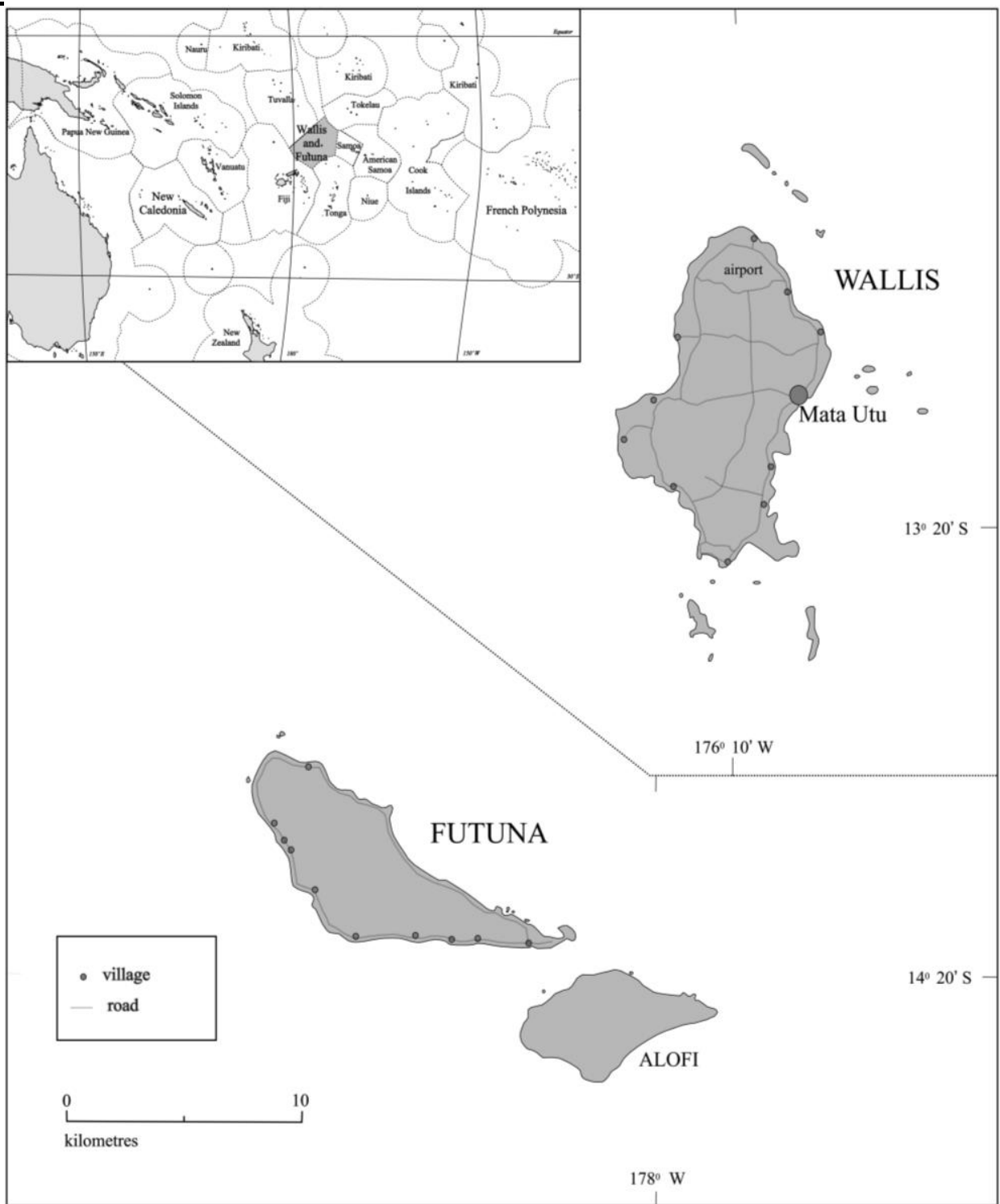

Source: Adapted by the authors from Secretariat of the Pacific Community, map: 'The Pacific islands', 2004. 


\section{Wallis and Futuna}

The following findings in this research are embedded within the complexity of the geographical, political, economic, and social structures of Wallis and Futuna, and understanding the context of this research is crucial in order to understand the findings in this study.

Wallis and Futuna is a dependent French collectivity (formerly territory) in the heart of the South Pacific (Figure 1). The population on the islands is in the majority Polynesian, French-speaking, and Catholic. From 1888, Wallis and Futuna fell under a protectorate of France until 1961 when the islands became a territory of France. The document outlining the islands' status, known as the statut de 1961 (or statute), states that Wallisians and Futunans are French citizens and are subjected to the same laws and rights ("Loi $n^{\circ} 61-814$ du 29 juillet 1961 conférant aux îles Wallis et Futuna le statut de territoire d'outre-mer (1)", Préfecture des îles Wallis et Futuna, 2012). The statute also acknowledges the state's respect over local customary traditions and authority. Since then, the French administration and justice system known as the droit commun (common law) and the customary Wallisian and Futunan justice system known as the droit coutumier (customary law) (van der Grijp, 2005) have coexisted. Different responsibilities and power are distributed among the French Administration (led by a prefect), the Customary Authority (led by three kings and high chiefs), the local political Territorial Assembly (led by a president), and the Catholic Church (further explained in IEOM, 2015). Although there is local political presence, the French Administration maintains a hold on the executive power and decision-making (IEOM, 2015). On the other hand, the customary authorities are given much responsibility. Customary chiefs oversee customary matters and three customary representatives (kings or chiefs), alongside the prefect, take part in the Territorial Committee where they can approve or reject projects before they are considered by the administration and the territorial assembly (IEOM, 2015). There is one kingdom on Wallis (Uvea) and two on Futuna (Alo and Sigave).

The economy of Wallis and Futuna is highly reliant on financial transfers from the French state, remittances, migration, networks, and access to labour employment in metropolitan France and other FODTs such as New Caledonia and French Polynesia (Connell, 1983; Angleviel \& Papilio-Hamagahu, 2014; van der Grijp, 2002, 2003, 2005; IEOM, 2015). Consistent with other SNIJs and MIRAB economies, association with the metropolitan state has brought higher standards of living relative to the rest of the region, along with many modern services such as free education, healthcare, television, internet, and most recently mobile phone services (Angleviel \& Papilio-Hamagahu, 2014).

Wage and salary employment is still relatively low, as only approximately $15 \%$ of the population were reported to be in official employment in 2015 (IEOM, 2015), though of course many people may be engaged in subsistence/non-waged work. The public sector is the main provider of formal employment and the private sector remains underdeveloped. The disparity of access to wages and remittances on the islands has forged growing inequalities in standards of living (Tafalagi, 2004) and increased wages have led to a growing middle class (van der Grijp, 2005).

There is now evidence of a decrease in subsistence-style living in favour of consumerism attributed to increased access to wages over the years (van der Grijp, 2002, 2003, 2005). Nevertheless, custom and religion continue to hold a significant place within society. There also continues to be an important gift, barter, and subsistence economy existing alongside a more modern monetary society (Tafalagi, 2004; van der Grijp, 2002, 2005). Traditionally, land is held in customary forms and transferred within kinship groups (Malau, 2004). 


\section{Education and the MIRAB system in Wallis and Futuna}

In Wallis and Futuna, the French educational system has been implemented on the islands and the pursuit of higher education is encouraged at high school. Due to a lack of facilities for higher education in the territory, students can access study grants ${ }^{4}$ to pursue further education after high school, commonly in metropolitan France, New Caledonia, and French Polynesia 5 . In the past 15 years, the pursuit of higher education overseas has become the norm for many young Wallisians and Futunans. For many, higher education is a pathway towards employment locally or overseas, satisfying modern 'wants' and achieving independence.

What interests the generations now is the salaries, money ${ }^{6}$ (Participant 50).

To provide access to higher education to a greater number of students, young people from lower income families are entitled to State and Territory bursaries. Young high school graduates can also access financial backing from local organisations that send people to acquire further qualifications and training (e.g. Service de l'Inspection du Travail et des Affaires Sociales SITAS and 40 cadres $^{7}$ ), or many also join the army to further their training in their field of choice. Although these programmes are in place to increase human capital at home, return for work is relatively uncommon and dependent on a different local political, economic, and social structure.

As briefly explained previously, the structure of the system in Wallis and Futuna stems from the amalgamation of two idealistic and functionally distinctive systems. In an attempt to consolidate an equal balance between tradition and modernity, and French and Polynesian, power and responsibilities are dispersed among the state, customary authorities, and local politicians. The state advocates for modernity and upholds the values of liberté, égalité, fraternité (liberty, equality, fraternity) in Wallis and Futuna, whilst local authorities try to maintain a traditional system based on hierarchical values of tout le monde a sa place (everyone has a place). According to some participants, this collision of distinct ideologies and political values has forged an interlocking system preventing local economic development.

As will be evidenced throughout this article, the role of higher education in Wallis and Futuna has consequently been heavily influenced by the particular structures of this system. Many participants highlighted the challenges for return and using their higher- education qualifications in a stand-still system that has limited opportunities.

\section{Education and the hinterland: a new population outlet}

While the structure of the system and its incentives has enabled more young people to access education and training opportunities overseas (an opportunity that many young people take), increased education is not matched with a structure or system that can welcome a return of these skills. Here, Baldacchino's concept of 'hinterland' (see footnote 1) is apposite. It sees the educational opportunities available in New Caledonia and metropolitan France from the perspective of young people in Wallis and Futuna as resources that they have access to and which can be exploited, whether or not they ultimately lead to a return home.

\footnotetext{
${ }^{4}$ Since the early 2000s, young students have had access to the territorial grant (bourse territoriale) (Préfecture des Îles Wallis et Futuna, 2016) and the state grant (bourse CROUS) (CROUS Paris, 2016). Financial support is granted depending on different social criteria (such as parents' income) which translate into a points system. All students are also entitled to a passport mobilité grant for travel costs (IEOM, 2015; LADOM, 2016).

${ }^{5}$ There are a few grants available for students wishing to pursue higher education in New Zealand and Australia. However, pursuit of higher education there is less common.

${ }^{6}$ «Ce qui intéresse les générations maintenant, c'est les salaires, les sous » (Participant 50).

${ }^{7}$ The SITAs and 40 cadres are programmes that financially support training courses overseas in the hope that it will increase human capital return to the territory.
} 
The possibility for Wallis and Futuna to benefit from this access to education is particularly dependent on employment opportunities locally, but in Wallis and Futuna these are very limited. This increase in access to higher education combined with a stagnant employment sector has caused significant disparity between labour availability and labour demand.

They (the parents and the territory) push us to continue our studies and tell us to do this and do that but after, when we come back and ask for a job, they say 'we don't have anything for you'. It gives us false hope ${ }^{8}$ (Participant 45).

Many young people aspire to employment in the bureaucratic sector (the largest provider of jobs in the territory), yet vacancies are extremely rare. Young participants criticised the administration for not creating new employment opportunities while participants in the bureaucracy complained of many redundancies as the decreasing population reduced the need for such a large bureaucratic sector. Participants complained that public sector employment is often at a standstill until someone resigns or retires.

In the civil service, it's only when they retire. They won't take young people like that. They don't want to create positions ${ }^{9}$ (Participant 43).

Typical of a MIRAB economy, the public sector is the largest sector on the islands and the high wages in the bureaucratic sector arguably prevent, or crowd out the need for, an active private sector. In addition, a lack of political and economic focus on economic activity means that employment in the private sector is limited and tools to assist business development are narrow.

But this (education) skill collides with an economy that is practically non-existent. There is a large portion of the young population that do not return because they have acquired knowledge that could be recognised and utilised within a business ${ }^{10}$ (Participant 9).

It is evident that local customary systems regularly clash with western economic business structures and requirements, deterring many prospective graduates from returning and contributing to this sector. In particular, local customary pressures of giving and sharing funds potentially hinder business growth, and customary land tenure prevents people from accessing large loans due to the absence of collateral. Customary land disputes and the absence of official cadasters further deter activity.

Participants also often criticised the fact that qualifications acquired in the French system were not suited for the context of Wallis and Futuna. This was particularly true for business development because requirements to set up a business in Wallis and Futuna are very different to those in France.

Overall, private sector employment in the territory appeared unattractive to young graduates.

This is why the private sector struggles to keep people (workers). It's because it isn't appealing. There are many young people, when they return and start an activity, they

\footnotetext{
8 « On nous pousse à aller continuer les études et à faire ceci et faire cela mais après quand on arrive on demande à entrer mais on te dit: 'on a rien à t'offrir'. Ça donne un faux espoir » (Participant 45).

9 «A l'administration, c'est seulement quand t'as des retraités. Ils ne vont pas prendre comme ça des jeunes. Ils ne veulent pas créer des postes » (Participant 43).

${ }^{10}$ «Mais qui se heurte aujourd'hui sur une économie qui est quasiment inexistante. On a une grosse partie de la jeunesse qui ne reviennent pas qui ont acquis un savoir-faire qui pourrait être valorise dans une entreprise » (Participant 9).
} 
always have an eye on a position that could be freed up at the civil service and then they go for it. After, they give up (their business) because they will be better paid, they will be worry-free ${ }^{11}$ (Participant 44).

The possibilities for return further are narrowed by the French system enforced in Wallis and Futuna which dictates that (the right) qualifications are required to access specific employment (for example, a hairdresser would have a hairdressing diploma and a teacher would have a teaching degree). In Wallis and Futuna, given the few opportunities, degree requirements will be specific and are sometimes higher than those required for corresponding positions in France. For those who do not succeed in their studies-a high occurrence for many who struggle with culture shock, financial difficulties, and so forth-availability of low-skilled employment in the destination, compared to Wallis and Futuna, is then another incentive to stay in the hinterland. The opportunity for people with few or 'wrong' qualifications to return and access employment is further constrained.

Furthermore, despite a strong desire to return for many, issues preventing return of young skilled (and unskilled) workers compelled many to use opportunities and resources accessible to them in the hinterland (metropolitan France, New Caledonia, and French Polynesia). Plans to stay in the hinterland are further enabled by education as better qualifications provide young people with better access to paid employment in their destination. Plans to stay in the hinterland are a common option for those who cannot or do not want to access waged employment at home. For this reason, programmes to help young people gain education and training have been seen as 'tourist agencies' and education is an 'easier exit route' for young people, rather than providing people with skills to eventually help the development of the territory.

I think they are programmes that influence people to leave. They're not programmes to incite the population to find solutions to stay in the territory ${ }^{12}$ (Participant 29).

Participants also stated that a new phenomenon has arisen as a result of migration and education. Previously, people would have been able to live in the islands without being employed or through having access to wages from other family members. Changing wants, expectations, and lifestyles, along with an increasing cost of living, means that unemployment is nowadays particularly difficult and unappealing for families; especially since there are no unemployment benefits in the territory. And although remittances continue to contribute, many people are choosing to join their family members abroad instead.

Before young people would send money to the parents and now they're sending money to pay for the flights ${ }^{13}$ (Participant 7).

On the other hand, although interviewees criticised skilled young people who chose to stay in the hinterland for not challenging the 'interlocking system' or contributing to local

\footnotetext{
${ }^{11}$ «C'est pour ça que le privé a du mal à garder ses emplois parce que ce n'est pas attirant. Il y a beaucoup de jeunes, quand ils reviennent et qu'ils commencent une petite activité, il y a toujours un regard vers un poste qui va se libère à l'administration et puis ils se sautent dessus. Après on laisse tomber parce il sera mieux payé et il sera plus tranquille $\gg$ (Participant 44$)$.

${ }^{12}$ « Je pense que ce sont des dispositifs qui incitent la population à partir. C'est pas des dispositifs pour inciter la population de trouver des solutions pour y rester sur le territoire parce que le service militaire, forcément il y a pas de bases militaires ici donc les jeunes sont forcés de partir ailleurs. Pareil pour la formation 40 cadres, une fois que le Wallisien et le Futunien est diplômé après sa formation, soit il a de l'emplois ici à Wallis, ou bien il est obligé de rester ailleurs pour trouver de l'emploi » (Participant 29).

${ }_{13}$ « Avant les jeunes renvoyaient de l'argent aux parents et maintenant ils envoient de l'argent pour les billets » (Participant 7).
} 
development, education and emigration was not always seen as negative. Education has provided people with greater access to employment in the hinterland and has alleviated pressures to create employment.

Thus, higher education and training was also viewed as an opportunity to benefit the individual young people, as it would provide them with greater opportunity to access employment abroad.

The objective is not that they return, it's that they succeed ${ }^{14}$ (Participant 16).

Although in orthodox understandings of 'sustainable development' this should be concerning, in the light of MIRAB development, the maintaining of this structure is the main foundation of relative economic stability for those who live in Wallis and Futuna. Additionally, given the system in place and the many challenges to development in the islands, many argued that the return of skilled people would potentially be more disruptive and unsustainable because the islands do not have the resources or structures to provide for this return.

We have so many young people here who leave and even if they came back with all the specific qualifications, we would struggle to recruit them, financially the territory does not have the means to ${ }^{15}$ (Participant 44).

Although the stability of remittances and transnational networks was not a focus of this study, it could be assumed that greater access to education is increasing the chances of emigrants being employed in higher-paid jobs in the hinterland and could potentially have a positive impact on remittances for families who choose to stay on the territory.

\section{Social dimensions in MIRAB}

In Wallis and Futuna, as in France, candidates go through a thorough interview process before being hired and qualifications are a key component of this selection process. However, the research highlighted how social classes have an important influence on people's employment opportunities locally.

In Wallis and Futuna, custom and customary hierarchy have maintained significant power politically and have remained a large part of people's lives. And it appears that, despite the French egalitarian system, customary hierarchy and traditions have been transferred to the employment sectors. In fact, a common theme in the research was the customary concept of 'place', particularly in terms of referring to someone's place in the social and customary hierarchy. Access to, and success in, employment was dependent on factors linked to a person's place such as land ownership, clan, village of origin, networks, and age. Many participants criticised the fact that due to these factors, return and access to employment would be easier for some than for others.

Many participants debated whether the aliki-the noble, customary families-mostly accessed employment or whether it was the bureaucratic elite classes who were prioritised. Some participants stated that the only people who were hired within the administration (including education) were all of aliki descent.

\footnotetext{
${ }^{14}$ «L'objectif, c'est pas qu'ils reviennent, c'est qu'ils réussissent » (Participant 16).

15 «On a énormément de jeunes ici qui partent et même si ils revenaient tous avec des diplômes spécifiques, on aurait du mal à les recruter, financièrement, le territoire n'a pas les moyens» (Participant 44).
} 
We need to take into account the social factors that say that it's the dominant clans, the aliki, that have the positions ${ }^{16}$ (Participant 10).

There are the aliki families here, the chiefly families, the noble families. For those, most of their children find work more easily ${ }^{17}$ (Participant 44).

Although, some participants denied these claims,

The young graduate has nothing to do with being aliki or not aliki. There are many young people who have returned whose father was village chief or former king but it doesn't necessarily mean that he'll find work here ${ }^{18}$ (Participant 33).

This observation that aliki families are prioritised in employment may also be attributed to the fact that education was previously reserved for these families, and with the recent changes in regulations, they may have been the only people to have the required qualifications for the positions.

And since employment and high wages have been accessible locally, there has been a rise of a 'new' bureaucratic class that has seemingly challenged this 'right' of place for aliki families in employment. As qualifications become further enforced for employment, bureaucratic families have been using access to education to enable them to continue to access employment at home. However, nowadays, these arguments are made more complicated as the delimitations between bureaucratic classes and the noble families are less clearly defined. There are now what we could call more 'dominant' or elite families who have gained status through a combination of employment, customary presence, political representation, and ancestral lineage.

Many participants additionally criticised customary land and village origin for taking precedence over qualifications in some employment opportunities. Customary land employment in particular was condemned as a significant barrier to development and barrier to the return of the skilled. Often, lower skilled employment was assigned to the families who owned the land or to people who originated from the village where the facilities or businesses were located. Customary land employment often appears in the local news as disputes over successful candidates cause businesses to close temporarily until the matter is resolved (often in favour of candidates chosen by landowners). Concerns over village chiefs and landowners being able to block activity was a deterrent for young people looking for employment or looking to set up a business in places located somewhere other than their local village or somewhere that is not owned by their families as village chiefs and landowners can block all activity.

We give jobs to families who own the land and, often, those people aren't qualified. And it's even more complicated to find work because either way, they're going to hire family members or we're going to find someone who has a diploma who is married to a family member ${ }^{19}$ (Participant 31 ).

\footnotetext{
16 «Il faut tenir compte aussi du facteur social qui dit que c'est le clan dominant, c'est à dire les aliki qui ont les postes » (Participant 10).

${ }^{17}$ «Il y a les familles d'aliki ici, les familles de chefs, les familles nobles, ceux-là la plupart des enfants trouvent plus facilement du travail » (Participant 44).

18 «Le jeune diplômé n'a rien avoir en faite avec le fait d'être aliki ou pas aliki. Il y a des cas de jeunes qui sont revenus dont le père était chef de village, le père était ancien roi, c'est pas pour autant qu'il trouve un travail ici » (Participant 33).

19 «On donne des postes aux familles propriétaires du terrain et souvent ces personnes là sont pas qualifiés. Et c'est encore plus compliqué de trouver du travail parce que de toute façon, on embauche la famille ou on ira chercher une personne diplômée, mariée à un membre de la famille » (Participant 31).
} 
If I take the example of this department, the highest qualification is a $b a c$ pro $^{20}$, no one else has a diploma. When the department was created, there was pressure to hire those people, or people from those families and who have since been replaced by other people from the same family ${ }^{21}$ (Participant 44$)$.

Another difficulty for return was the idea that young people with different ideas and views were not often accepted. They would be labelled papalagi (foreign). Some participants believed that returnees with new ideas for the future needed to return and conform to the traditional ways of introducing ideas (through the customary authorities) and had to introduce ideas that were adapted for the local context, otherwise these ideas would be disruptive.

The concept of age and respect is another concern for young people since, in the traditional system, respect is given to elders. Participants argued this concept could transfer into employment. Some stated that an elder of higher status could be hired over a young qualified returnee. It was also said that there is evidence that the system is changing as qualifications are reinforced as a requirement and more young people from different backgrounds are hired. Nevertheless, people's ability to prove themselves in the workplace might still be hindered by their age and their social standing.

Nowadays, as a young person, we're encouraged to leave, to study, so we go. The problem is that when we return, we don't have our place in society. Whether it is in the administration or in custom, we don't have our place ${ }^{22}$ (Participant 38).

Additionally, some participants argued that those with larger families had better chances of finding employment and their ideas being heard because the customary gifts and gestures of such families would be larger and have greater significance. A larger family would also have greater representation within the community and within society. Larger elite families in particular would be more likely to be employed in the bureaucratic sectors or have customary land and would then be better able to provide jobs to other family members.

You're only recognised really if you belong to a group. You on your own, we don't know you. If you're alone, it's hard to make yourself known ${ }^{23}$ (Participant 31).

Now, it isn't about lineage because many have left, but it is about the customary representation of a family ${ }^{24}$ (Participant 17).

In fact, nepotism was a significant concern for young participants in particular. Many highlighted that people with connections (often the more 'dominant' families) in the workplace were more likely to be hired. As a result, some participants have criticised nepotism as hindering the return of qualified students.

\footnotetext{
20 a high school qualification.

${ }^{21}$ «Je prends l'exemple au service ici, parmi nos 7 agents, le niveau plus élevé c'est un bac pro, tous les autres ce sont des agents non-diplômés. Parce que quand l'antenne a été créée en 2005, il y a eu des pressions pour embaucher ces gens-là, ou des gens de ses familles là et qui ont été remplacé par des gens de la même famille depuis » (Participant 44).

${ }^{22}$ «Aujourd'hui en tant que jeune, on est encouragé de partir et à faire des études. On y va. Le problème c'est qu'en revenant, on a pas notre place dans cette société. Que se soit administratif, que ce soit coutumière, nous on a pas notre place » (Participant 38).

${ }^{23}$ « Tu n'es reconnus enfaite seulement si tu appartiens à un groupe. Toi seul, on te connait pas. Si tu es seul c'est dur de se faire connaître » (Participant 31).

${ }^{24}$ « Maintenant, c'est plus le sang mais dans la mesure où les gens sont partis, la famille la plus représentative coutumièrement unie » (Participant 17).
} 
Most of the positions that are taken at the civil service are people from the same family. It's all from their connections ${ }^{25}$ (Participant 18).

In addition, some participants argued that the customary tradition of giving to the village chiefs, family, the community, and to people with significant mana in society could improve a person's relations and representation. Some participants criticised that this act of giving could be used as a form of bribe to help someone find employment.

Due to nepotism and customary favouritism, whether qualifications were taken into account was seen as debatable.

It is based on equal qualifications and then there is a bit of favouritism based on their familial situation, on this customary and political hierarchy ${ }^{26}$ (Participant 44).

There are graduates here who don't have a job and there are some who aren't qualified who have a job ${ }^{27}$ (Participant 39).

In other types of employment, qualifications are still not required. In particular, customary responsibilities and elected politicians were not assigned based on qualifications but candidates were voted in according to their ancestral lineages, their customary and social representation, and their connections. Furthermore, some participants believed that those who left Wallis and Futuna could potentially lose the right to access these positions because they were seen as 'polluted' with outsider views and, during their time abroad, they would not have been able to maintain crucial customary representation locally.

With the importance of place and connections with society, it could be argued that those who hold customary power in Wallis and Futuna are informally maintaining a hold on who can return and access employment. People may be free to come and go but their ability to access positions of influence or well-paying employment is effectively controlled by customary gatekeepers. In doing so, the process of societal and cultural change is slowed and regulated.

The role of education in the MIRAB system here is evident as social classes negotiate how migration for education can be beneficial to them. For some, education provides a 'ticket home', qualifications that allow them to build on their social position and secure stable and lucrative employment in the public sector. For others, education serves as 'ticket out' - those who do not have a privileged place at home are able to access job opportunities overseas. Due to this interaction between classes as a result of education and employment, there has been evidence of a slowly transforming society. A sort of balance and stability is achieved-emigration provides a safety valve for surplus population that cannot find an adequate livelihood at home-yet we could suggest that a long-term metamorphosis is taking place as the customary and bureaucratic elites have a secure footing at home (and can also move internationally) and thus become a larger proportion of the resident population, whilst the less privileged tend to leave and may become increasingly detached from their customary home and society.

The social system has simultaneously sustained traditional hierarchy, provided power to a new elite, and strengthened the MIRAB structure of dependent development. Bureaucracy

\footnotetext{
${ }^{25}$ «La plupart des postes qui sont occupés à l'administration supérieure ce sont les gens d'une même famille. Ça a été du copinage » (Participant 18).

${ }^{26}$ «Les enfants de chefs de villages, d'élus, arrivent à occuper des postes plus facilement. - avec diplômes quand même. Compétences égales et puis il y a un peu de favoritisme en fonction de cette situation familiale et de cette hiérarchie coutumière et politique » (Participant 44).

27 «Il y a des diplômés ici mais qui n'ont pas de travail et il y en a qui sont pas diplômés qui ont du travail » (Participant 39).
} 
and the bureaucratic classes are a significant characteristic of the MIRAB model, but in this case it is not only the bureaucratic classes that are sustaining the MIRAB, it is also the customary classes. It could be argued that the MIRAB is being sustained by the social classes because (i) the state will have to continue to provide subsidies for customary and bureaucratic wages; (ii) through restricting the return of skill and new ideas, activity and economic development is also restricted and dependence on aid is maintained; and (iii) populations that do not fit the social and customary requirements are being further crowded out, potentially creating further networks of migration and remittances.

\section{Accessing employment at home: a future MIAB economy?}

Despite the above arguments, it is also evident that the importance of place for employment is diminishing and it may be that gradual social change, rather than social ossification, is being encouraged by migration for education.

At one time, we often gave jobs to noble families so they didn't necessarily require diplomas or specific qualifications and often those positions were taken by people who came from royal descent. In fact, some are still in those positions. And at one point, it was complicated for the rest to find work. But it happens less and less because now, they're asking more and more for qualifications ${ }^{28}$ (Participant 31).

In fact, increased access to employment at home appeared to be the main motivator for some for higher education and for return. Encouraged by the territory and encouraged by their own motivations, many directed their studies towards employment that was available in Wallis and Futuna to provide them with better prospects for return. Mostly, young people directed their studies to provide them with access to employment in the public sector because of the greater employment opportunities, better wages, and better employment security, particularly in teaching.

Everyone wants to go into teaching because you're sure that they're going to give you a job $^{29}$ (Participant 45).

As a result, a recent surge in migration for higher education has provided a larger proportion of the local populations with the opportunity to access employment in the territory, as qualifications progressively become a requirement for employment, despite social and customary requirements. In fact, many argued that access to higher education has made way for a 'turnover' or localisation of employment-expansion of employment opportunities is occurring not through competition amongst locals but through replacing expatriates in government service.

We need qualifications here, especially to occupy the 'papalagi' positions. To be a professor, a head teacher, a head of department, they require a diploma, which are many years of $\operatorname{study}^{30}$ (Participant 45).

\footnotetext{
28 «A une époque, je sais qu’on donnait souvent des métiers à des familles nobles donc on exigeait pas forcément de diplômes ou de qualifications particulières et souvent ces postes là sont occupés par des gens qui sortent de lignée royale. D'ailleurs, il en reste encore. Et à un moment donnée, c'était compliqué pour le reste de trouver du travail mais ça ce fait de moins en moins parce que maintenant, ils demandent de plus en plus de qualifications » (Participant 31).

${ }^{29}$ «Tout le monde veut aller dans l'enseignement parce que t'es sûr qu'on va te donner un poste. Tu t'investis entièrement et tu sais qu'on va te donner un poste sur Wallis et Futuna» (Participant 45).

30 «Il faut des diplômes ici, surtout pour occuper les postes des papalagis. Comme professeur, principal, ou chef de service, ils exigent des diplômes. C'est beaucoup d'années d'études» (Participant 45).
} 
Equal access to education has also driven up competition for employment at home. This is because employment opportunities are still limited in Wallis and Futuna and employment demand has increased as more people have gained qualifications required at home. With the change of aspirations and increased consumerism, employment at home has become a key motivator for young people to pursue higher education and try to return. Upon hearing of a vacancy, many potential applicants return to the territory to apply-making these positions extremely competitive.

People who I studied with and who now work in New Caledonia, they are on the Internet every day, looking to see if there is an opportunity that might open up here ${ }^{31}$ (Participant 38).

This competition highlights that there is limited labour shortage (and probable excess supply), in the bureaucratic sector in particular. Furthermore, it would seem as if the re-entry barrier is rising, in terms of competition and requirements for ever-higher qualifications and abilities. Although there was evidence of young qualified people returning to create a business or develop an activity, the numbers are still very low due to the barriers for business development in the territory.

Furthermore, despite the difficulties for return attributed to social structures, there was evidence that a large number of young people did persevere and tried to access employment, regardless of their social standings and connections. And as perceptions towards qualifications and employment change and as qualifications are reinforced as a requirement, access to employment may be more equal. As long as people from different backgrounds do not become discouraged and continue to return with their skills to access employment, the system on the ground may change and social cultural determinants of employment may have less leverage.

For me, this system is very old, we need to be able to live with the times. Nowadays, if you have a job and you want to do well in it, you're not going to let someone come and walk all over you because you've pursued higher education and it's not because someone with noble ancestry or a noble name that they're going to impose anything ${ }^{32}$ (Participant 58).

In fact, although many continue to rely on subsistence farming and continue to practice gifting and barter on the islands, this lifestyle is slowly changing, as young people are encouraged to visit the hinterland, pursue higher education and find employment, as opposed to staying in the villages to help their family. Some argued that the younger generations look towards consumerist lifestyles, which largely require waged employment. Therefore, for those who want to return and enjoy a more-than-subsistence way of life, education is really the only solution. Indeed, many participants emphasised that employment was one of the reasons that allowed them to stay and, in many cases, one person's wage was enough to support their family members. And because employment was so difficult to come by and wages were particularly high (especially in the bureaucratic sector), people rarely left their jobs in Wallis and Futuna.

As a result, it appears that employment in Wallis and Futuna, in the public sector in particular, has become the principal financial safety net for kinship groups and is becoming the

\footnotetext{
31 «Les jeunes qui étaient avec moi et qui aujourd'hui travaillent en Nouvelle Calédonie, tous les jours ils sont sur internet à guetter pour voir si y a pas un emploi qui va se libérer ici » (Participant 38).

32 «Pour moi ce système est très vieux, il faut savoir vivre avec son temps. Là au temps ou on en est, si toi t'as un travail et tu veux prospérer dedans, tu vas pas laisser quelqu'un venir te marcher dessus parce que toi t'as fait de grandes études » (Participant 58).
} 
only way families can afford to remain on the territory. And as mentioned in a previous section, a growing number of unemployed families are choosing airline tickets out of Wallis and Futuna over remittances from family members abroad. Although a proportion of the population in Wallis and Futuna continue to rely on remittances from kin, access to high wages in Wallis and Futuna has gained priority. It could be argued that a continued lack of opportunities for economic activity and a continued focus on employment in the bureaucratic sector could direct Wallis and Futuna into a future where bureaucratic wages act as a social security system, as hypothesised by Watters (1987).

Thus, although education is providing a new population outlet, it is also enabling some people to return. Return of these skilled people is helping reinforce the stability as it is providing young people with the opportunity to enter the bureaucratic sector, and in a sense maintaining and strengthening the 'bureaucratic' component of the MIRAB in particular.

\section{Conclusion}

Education, as a newer but key component in the MIRAB in Wallis and Futuna, has affirmed existing theorised concepts in the MIRAB literature and has also brought to the forefront significant new dimensions and concepts to the MIRAB model.

In development practice and research, education has a role to increase human capital with the long-term purpose to increase economic development. However, there is an apparent tension between the traditional understandings of education in development and the tenets of the MIRAB. It appears that the structure of the MIRAB system is simultaneously the underlying enabler and inhibiter of potential benefits from higher education and training. Whilst education is undoubtedly providing substantial benefits and pathways for development at both individual and national levels, these benefits and pathways have to be transacted through a complex and often contested web of social, cultural, and political understandings and processes locally.

This research has suggested that the MIRAB system in Wallis and Futuna has elements of complexity and diversity that we have not fully appreciated to date. Firstly, education should be seen as a critical process within MIRAB territories. The case of Wallis and Futuna has illustrated how education acts as a sort of lubricant for the system. It eases the movement of young people out of the territory, initially for higher education but also for longer-term resettlement overseas. It can also enable the return of some to well-paid bureaucratic positions at home. Secondly, we have seen in this case study the critical importance of the bureaucracy element (Poirine, 1994) but also implied that the remittance element may not be so important (Ogden, 1989). In territories such as Wallis and Futuna with close ties to the metropole and where the public sector is structured, maintained, and supported by the metropole, not only is this virtually the only employment option (for tourism and other private-sector activities are limited) but also it is particularly lucrative and attractive, allowing employees to enjoy both a material lifestyle comparable to the metropole and maintain a life 'at home' with the benefits - and costs - of customary ways of life and relationships. Yet, in such a situation, return home is not as in some MIRAB societies only a poor option and a social safety net, but rather a highly desired option for those who gained education abroad. Rising entrance standards for such positions, albeit with a possible shrinking volume, is leading to a gradual social transformation: the population through MIRAB is not necessarily becoming older, less skilled, and dependent on remittances but rather it is being reinvigorated with well-qualified (and often wellconnected) returnees on high incomes. On the other hand, those who cannot access such positions seem to have chosen to use their education to access opportunities for themselves and their families in the hinterland. 
The role of education here has contributed to Bertram's (2006) argument that the MIRAB model is not static but continues to be moulded to fit with external and internal changes of the components. While we could assume that the MIRAB structure within Wallis and Futuna will continue to rely on migration, remittances, aid, and bureaucracy, how it functions will continue to change as components such as education become more visible in the kaleidoscope. Although it is difficult to predict the future of the MIRAB (Bertram, 2006), it is unlikely that Wallis and Futuna will leave the MIRAB mould or transform into a PROFIT or SITE economy. Nevertheless, education may have contributed to the shaping of a new MIRAB stability and provided potential for a post-MIRAB economy.

\section{References}

Angleviel, F., \& Papilio-Halagahu, B. (2014). Wallis et Futuna 3500 ans d'histoire. Nouméa: GRHOC.

Baldacchino, G. (2006a). Managing the hinterland beyond: two ideal-type strategies of economic development for small island territories. Asia Pacific Viewpoint, 47(1), 4560. https://doi.org/10.1111/j.1467-8373.2006.00295.x

Baldacchino, G. (2006b). Innovative development strategies from non-sovereign island jurisdictions? A global review of economic policy and governance practices. World Development, 34(5), 852-867. https://doi.org/10.1016/j.worlddev.2005.10.004

Baldacchino, G., \& Milne, D. (2006). Exploring sub-national island jurisdictions: an editorial introduction. Round Table, 386, 487-502. https://doi.org/10.1080/00358530600929735

Beine, M., Docquier, F., \& Rapoport, H. (2008). Brain drain and human capital formation in developing countries: winners and losers. The Economic Journal, 118(528), 631-652. https://doi.org/10.1111/j.1468-0297.2008.02135.x

Bertram, I.G. (2006). Introduction: The MIRAB model in the twenty-first century. Asia Pacific Viewpoint, 47(1), 1-13. https://doi.org/10.1111/j.1467-8373.2006.00296.x

Bertram, I.G. (1993). Sustainability, aid, and material welfare in small South Pacific Island economies, 1900-1990. World Development, 21(2) 247-258. https://doi.org/10.1016/0305-750X(93)90020-A

Bertram, I. G. (1986). 'Sustainable development' in Pacific micro-economies. World Development, 14(7), 809-822. https://doi.org/10.1016/0305-750X(86)90033-1

Bertram, I.G., \& Watters, R.F. (1985). The MIRAB economy in South Pacific microstates. Pacific Viewpoint, 26(3), 497-519.

Connell, J. (2008). Niue: embracing a culture of migration. Journal of Ethnic and Migration Studies, 34(6), 1021-1040. https://doi.org/10.1080/13691830802211315

Connell, J. (1983). Migration, employment and development in the South Pacific: Wallis and Futuna Islands. Noumea: South Pacific Commission.

CROUS Paris. (2016). Bourses sur critères sociaux. Retrieved from http://www.crousparis.fr/bourses/bourses-sur-criteres-socieaux/

Evans, M. (1999). Is Tonga's MIRAB economy sustainable? A view from the village and a view without it. Pacific Studies, 22(3), 137-166.

Gibson, J., \& Mckenzie, D. (2012). The economic consequences of 'brain drain' of the best and brightest: microeconomic evidence from five countries. The Economic Journal, 122(560), 339-375. https://doi.org/10.1111/j.1468-0297.2012.02498.x

Hau'ofa, E. (1995). Our sea of islands. In E. Waddell, V. Naidu and E. Hau'ofa (Eds.), A new Oceania: Rediscovering our sea of islands (pp. 38-48). Suva, Fiji Islands: University of the South Pacific.

Hughes, H. (2003). Aid has failed the Pacific. Issue Analysis no. 33. Sydney: The Centre for Independent Studies. 
IEOM (2015). Wallis-et-Futuna Rapport Annuel 2014. Nouméa, New Caledonia: Institut d'Emission d'Outre-Mer.

INSEE (2014). Wallis et Futuna a perdu près du cinquième de sa population en dix ans (pp. 1-4). Paris: Institut National de la Statistique et des Etudes Economiques.

Jacobs, A.C. (2016) Exploring the role of education in a MIRAB economy: nrain drain or brain gain? The case of Wallis and Futuna. Unpublished MDevStuds thesis. Wellington, New Zealand: Victoria University of Wellington.

LADOM (2016). Passeport mobilité-étude. Retrieved from http://pme.ladom.fr/

Malau, A. (2004). Culture and agriculture. In E. Huffer \& M. Tui (Eds.), Uvea (pp. 165-191). Suva: Institute of Pacific Studies, University of the South Pacific and Mata'utu: Service des Affaires Culturelles de Wallis.

McElroy, J.L. (2006). Small island tourist economies across the life cycle. Asia Pacific Viewpoint, 47(1), 61-77. https://doi.org/10.1111/j.1467-8373.2006.00303.x

McElroy, J.L., \& Hamma, P. (2010). SITEs revisited: socioeconomic and demographic contours of small island tourist economies. Asia Pacific Viewpoint, 51(1), 36-46.

https://doi.org/10.1111/j.1467-8373.2010.01412.x

McElroy, J.L., \& Parry, C. (2012). The long-term propensity for political affiliation in island microstates. Commonwealth \& Comparative Politics, 50(4), 403-421. https://doi.org/10.1080/14662043.2012.729727

McElroy, J.L., \& Pearce, K. (2006). The advantages of political affiliation: dependent and independent small-island profiles. Round Table, 386, 529-539. https://doi.org/10.1080/00358530600931285

Oberst, A., \& McElroy, J.L. (2007). Contrasting socio-economic and demographic profiles of two, small island, economic species: MIRAB versus PROFIT/SITE. Island Studies Journal, 2(2), 163-176.

Ogden, M. (1989). The paradox of Pacific development. Development Policy Review, 7(4), 361-373. https://doi.org/10.1111/j.1467-7679.1989.tb00138.x

Pacific Community (2016). Pacific island populations. Retrieved from http://sdd.spc.int/en/news/latest-news/124-population-projections-by-pacific-islandcountries-and-territories

Poirine, B. (1998). Should we hate or love MIRAB? The Contemporary Pacific, 10(1), 65105.

Poirine, B. (1994). Rent, emigration and unemployment in small islands: The MIRAB model and the French overseas departments and territories. World Development, 22(12), 1997-2009. https://doi.org/10.1016/0305-750X(94)90188-0

Poirine, B. (1993). Le développement par la rente dans les petites économies insulaires. Revue économique, 44(6), 1169-1199.

Préfecture des Îles Wallis et Futuna (2012). Loi $n^{\circ} 61-814$ du 29 juillet 1961 conférant aux îles Wallis et Futuna le statut de territoire d'outre-mer (1). Préfecture des Îles Wallis et Futuna.

Préfecture des Îles Wallis et Futuna. (2016). La bourse territorial sur critères sociaux. Retrieved from http://www.wallis-et-futuna.pref.gouv.fr/vos-demarches/Dossiersde-Bourse

Tafalagi, V. (2004). Discussing aga'i fenua or custom in Uvea. In E. Huffer \& M. Tui (Eds.), Uvea (pp. 134-144). Suva, Fiji Islands: Institute of Pacific Studies, University of the South Pacific and Mata'utu: Service des Affaires Culturelles de Wallis.

Treadgold, M. (1999). Breaking out of the MIRAB mould: historical evidence from Norfolk Island. Asia Pacific Viewpoint, 40(3), 235-249. https://doi.org/10.1111/1467$\underline{8373.00095}$ 
Vaioleti, T.M. (2006). Talanoa research methodology: a developing position on Pacific research. Waikato Journal of Education, 12, 21-34.

Vakala. (2008). 520 Boursiers de Wallis et Futuna préparent la rentrée. Retrieved from http://www.vakala.net/page-actu-article-1228.htm

van der Grijp, P. (2005). Development Polynesian style: contemporary Futunan social economy and its cultural features. The Journal of the Polynesian Society, 114(4), 311. van der Grijp, P. (2003). Between gifts and commodities: Commercial enterprise and the trader's dilemma on Wallis ('Uvea). The Contemporary Pacific, 15(2), 277-307. https://doi.org/10.1353/cp.2003.0057

van der Grijp, P. (2002). Selling is poverty, buying a shame: representations of work, effective leadership and market failures on Wallis. Oceania, 73(1), 17-34. https://doi.org/10.1002/j.1834-4461.2002.tb02804.x 